Jon Gower - Andrea Rožić

\title{
Prehladno za snijeg
}

Na ovim je sjevernim zemljopisnim širinama temperatura od 17 stupnjeva ispod ništice bila pravo ljeto. To je najhladnije nastanjeno mjesto na zemlji. Pričalo se da se jedan starac na trenutak zaustavio jednog popodneva i krv mu se sledila u žilama. Stoga su Eveni, nomadski narod, s razlogom nastavljali svoj put, uostalom, samo su držali korak sa životinjama. Njihov bog Hovki stvorio je sve oko njih, iako su pojedinosti o tome kako je to činio pomalo nejasne. Ipak je to bilo jako davno, no oni znaju da pripadaju svemu ovome, svemu oko sebe i prirodi, kao da im je rođak. Njihova riječ za medvjeda ista je kao ona za djeda. I dovoljno dugo su tu da bi znali da starješine lete prema suncu na leđima sobova.

Životinje su se teškim korakom kretale po mahovini, a njen je paperjasti prekrivač upijao svaki zvuk. Kroz nepregledni gustiš breza tanke zrake sunca, poput bambusovih stabljika, pokazivale su smjer, a tajga se činila kao da joj nema kraja. Goniči sobova zgrbili su se od hladnoće, a krhki se led hvatao za slojeve sirove kože i krzna koji su ih poput kukuljica branili od zraka na kojem se sve smrzavalo kao u tekućem dušiku. A tempom od pet milja na dan uz životinje probijao se i Boz koji je na ove ledene sibirske temperature došao kako bi pobjegao od žene.

Više se radilo o bijegu od osvetničkog klana njezine obitelji koji se, žestinom koja je graničila sa strastvenom požudom albanske krvne zavade, zakleo da mu nikada neće oprostiti što ju je ostavio u škripcu. Njihovo je kolektivno pamćenje bilo dovoljno selektivno da zaborave da je ona bila ta koja je pobjegla s upraviteljem Nasmiješenog kebaba. Nasmiješenog kebaba, jebemu sve!

Boz je bio skladatelj reklamnih džinglova, a sada je živio s nomadima s onu stranu Verhojanskog gorja. Zimi su nosili sedamnaest slojeva odjeće, ali on in je nosio osamnaest, za svaki slučaj. Mjesecima se nije dosjetio nijedne pjesmice jer je vidio kako ubijaju soba ubodom noža u dno lubanje. Neobično je kako se život čini kao ravna cesta, a onda se odjednom potpuno izokrene. Punica je ismijavala njegovu muziku - rekla je da se obrazovao preko svojih mentalnih kapaciteta. Od njenih se riječi znao smežurati od srama. Tako da je bio u bijegu od barem dvije žene. 
Ritam koraka potiče na razmišljanje, a sibirska je vrsta probijanja po oštroj zimi najplodonosnija. Jedan korak. Dva koraka. Još jedan. Tako mehanička radnja ostavlja vremena za razmišljanje o stvarima dok te sobovi obavijaju ogrtačem od smrznutog daha.

Boz je razmišljao o svojoj ženi i Lenu McLarenu - baš su bili jedno za drugo. Svatko tko može pasti na čovjeka s janjećom mašću od kebaba pod noktima, zavrjeđuje da ga se njima nepristojno i nehigijenski ispipka. Od pomisli na njegove ruke na njenoj koži u početku mu je bilo muka, zatim je uskuhao od bijesa, a onda je završio na mračnom mjestu. Neko je vrijeme pio kao da si to može priuštiti. Ako je tekila pogonsko gorivo za ludost, on ju je srkao do dna, iskapljivao kao da je Meksikanci krijumčare preko planinskog lanca Brecon Beacons na karavani mula, ili tankerima. Ali svako toliko netko bi neprijatno spomenuo da Thompsoni, paklena obitelj njegove žene, spremaju osvetu - da će ga gledati kako gori viseći na vješalima iz kućne radinosti. Na neki način Thompsoni su bili dovitljivi. Bili su obitelj koju treba izbjegavati. Njih i njihova vješala.

U rijetkim naletima trezvenosti razmišljao je o drastičnim načinima bijega iz svoje nevolje, čak je pomišljao da se pridruži francuskoj Legiji stranaca dok mu Mel, barmenica s cijelim zoološkim vrtom životinjskih tetovaža, nije rekla: "To je zamišljeni otok za žilave gejeve koji se vole igrati s kulama od pijeska." Znala je biti tako negativna - Mel, koja je studirala na Sorboni, ali je otkrila crack uz pomoć Marokanca džankija na grobu Jima Morrisona i izgubila se u velikim prostranstvima Europe zahvaljujući nevjerojatnim halucinogenima i kokainu bolničke kvalitete. Ona mu je pokazala oglas u Western Mailu u kojem televizijska kompanija sa sjedištem u Galwayju traži govornika velškog jezika, u dobroj formi, s istančanim smislom za avanturu, koji bi proveo godinu dana s Evenima, narodom goniča sobova, koji sa stokom putuju preko cijelog Sibira. Jedan od njihovih drevnih puteva uskoro će presjeći izgradnja golemog cjevovoda. Posljednja migracija Evena, kako su rekli u prilogu Radio Timesa.

Ozbiljno je shvatio ovu ideju i prije odlaska na razgovor prestao je piti i počeo se penjati na planinu Twmbarlwm dva puta dnevno dok mu listovi nisu postali kao oni bolivijskih gauča na Antiplanskoj visoravni. Unovčio je svoje državne obveznice, prodao auto i sav novac dao u zamjenu za vožnju starim sovjetskim helikopterom koju je dogovorio s biznismenima rumenima od votke koji su izgledali kao da odijela kupuju u butiku koji se zove Mafia 'R' Us. 
Helikopter je uzletio s vojnog aerodroma po kojem su bili raštrkani pokvareni stari Antonovi, hrđavi avioni kao ostaci carstva koje je potrajalo samo sedamdeset godina. Scena iz jednog od onih crnobijelih filmova o Hladnom ratu, pogotovo kad je ledena izmaglica progutala sve uokolo. Let je trajao čitavu vječnost zato što su se svako toliko morali zaustavljati da pokupe "poštu", slijećući na piste veličine vrtnog puteljka gdje nikada nije bilo nijednog pisma koje je trebalo preuzeti ili dostaviti. Ali su zato dostavljali sanduke alkohola i preuzimali životinjske kože, no znao je da ne treba pitati zašto ili s kojom svrhom. Pilot je znao par riječi lošeg engleskog. Iz usta mu se širio opojni miris karijesa i šljivovice i mahao je prstom veličine safalade naglašavajući svaku pobjedonosnu riječ. "Ti..."

"Da, ja...", reče Boz, nudeći lažni smiješak ohrabrenja najbolje što je mogao, shvaćajući da mu, kad se uključe propeleri, o ovom čovjeku ovisi život. I da je popio malo više od kapljice alkohola.

"Ti, ti se sviđa?"

"Da, jako."

"Što se sviđa?"

"Jako dobar helikopter. Čvrst i solidan. I ti, ti si izvrstan pilot. Sve te breze koje treba izbjeći. I ti to uspijevaš tako vješto."

"Koji znak?"

"Koji znak?"

"Koji znak si?"

"Koji znak?"

"Ja, jarac."

"Aa, misliš horoskopski znak? Ja, djevica."

"Donosi sreću?"

"Mislim da da."

"Treba ti kamo ideš." 
S tim je riječima pilot medvjeđe građe otišao u prednji dio helikoptera, kako god se to zvalo na helikopteru, i ostavio Boza da probavi smrznutu lokvicu straha koja mu se smjestila u dnu trbušne šupljine. Slažu li se jarci s djevicama? Je li pilot primijetio da su onaj red krošnji izbjegli za dlaku vjeveričjeg repa?

Boz je bio na boljim putovanjima od ovoga. Zapravo bi radije prošao kroz Had sa svojom bivšom ženom nego slušao škripanje propelera koji su zvučali kao da su, recimo, hrđavi, iako sada podmazani, ali na grozan način. Najozbiljnije, radije bi džogirao paklom u odijelu polivenom benzinom. Pomislio je na svoju majku, koju je kasno zavolio - bila je snažna, nemoguće pričljiva i ponosna na njega što god napravio. To je bila ljubav koju je ostavljao za sobom.

Osamnaest sati i dva strmoglava slijetanja kasnije stigli su na dogovoreno mjesto susreta. Bio je mrkli mrak, a takvu potpunu tminu Boz je doživio samo jednom, kad ga je baka za kaznu zaključala u ormar ispod stepenica jer je ukrao pivo od đumbira.

Sibirske zvijezde bile su skrivene, a mjesec na tamnoj strani. Kad su ga otpravili i iskrcali njegove torbe, bio je siguran da će pričekati do jutra, ali brzinom koja bi mu oduzela dah, da to već nije učinila hladnoća, helikopter i njegova posada ostavili su ga tamo, dok je ploča s instrumentima bacala demonski zeleni sjaj na pilotovo lice. Ostavili su ga usred Sibira, samo s termosicom da ga grije.

Ali došli su, šmrcajući nosovima, deset obitelji i stotine njihovih životinja, od kojih nitko nije znao niti riječi ruskog ili engleskog, samo nježne riječi evena, jezika koji je zvučao kao da je satkan od mahovine. Eveni, čije je vrijeme istjecalo. Snimajući njihovo svakodnevno putovanje dugo četiri milje, dok im je dah ostavljao tanku nit magle u zraku, Boz je shvatio da svjedoči povijesti u nastajanju; bio je to nomadski put koji će ubrzo presjeći. Sjetio se trenutka kad je vidio sive kitove na putu prema Aljasci kako slijede drevne tragove u moru i žele samo sjeći more svojim tijelima, usisavajući planktone i meduze u prolazu, dok su im jedino društvo lepršave njorke u letu.

Sobovsko meso, sasušeno poput pemikama, bilo je njihova glavna hrana. Ali bilo je i sobovskog mlijeka, i uvečer, fermentiranog sobovskog mlijeka, posluženog iz mjehova koji su prije toga vjerojatno bili sobovska utroba. Premda je ovo čudno pivo imalo pokoju dlaku i prenosilo se s usana koje nikada nisu vidjele četkicu za zube, bilo je nečega prekrasno utješnog u sporom 
djelovanju alkohola, šuškanju životinja utaborenih ispred šatora i povremenom smiješku djece koja su bila umotana u toliko slojeva krzna da je uhvatiti njihov pogled bilo pravo postignuće.

Svaki put kad bi postavili logor, vatru je trebalo pošpricati votkom da se umire zli duhovi. Jedan zli duh u zamjenu za drugi, pomislio je Boz. Palili su drvo planinskog rododendrona koje je mirisalo božanstveno. U novi šator stavili bi svježe grane ariša na tlo i okolo kamenjem pričvrstili kože sobova, a opojna mješavina aroma bila je dovoljna da čovjeka obori na tlo. Zvonca na sobovima koja su ih štitila od vukova Boza su podsjećala na jahte.

Svaki je dan bio ponavljanje prethodnog, pucketanje raštrkanih grančica breze pod nogama, nijemi rituali pokreta dok pokušavaš pišati na temperaturi ispod nule. Pročitao je previše priča o arktičkim istraživačima kojima je kad su skinuli čarape otpalo nekoliko prstiju. Boz je mokrio kao da se utrkuje. U ovom svijetu, hladnoća je beskrajno, osnovno stanje. Toplina je luksuz, prolazni trenutak. Nema zaustavljanja.

Hodali su već tjedan dana. Jednom su prošli pored stijene koju je raskolila vodena bujica i u čijoj su se unutrašnjosti vidjele gotovo netaknute kosti mamuta - životinja koje su prve kljovama zagrabile riječno blato i stvorile kopno. Boz je čekao pošiljku baterija koje je helikopter trebao dostaviti u blizini nalazišta nafte označenog na karti crtežom crnog vodoskoka. To je bila jedna od samo tri oznake na karti koju mu je pilot na brzinu nacrtao za dobru cijenu. Na njoj je bila i vojna nastamba, označena pištoljem i malo brdašce koje je bilo geološka nepoznanica.

Goničima su njegove karte bile blesave. Nisu imali ni jednu jedinu čvrstu točku u svom pogledu na svijet i sve su opisivali u odnosu na svoje kretanje kroz prostor. Duy je bilo trenutno logorište, ali samo privremeno dok ne postane dom, ali i polazište iduće seobe i te su se tri riječi izmjenjivale u krug - amdip, duy, erimken - prethodno logorište, trenutno logorište, iduće logorište - amdip, duy, erimken - trojstvo pokreta.

No iako su bili na pravom mjestu pravog dana, helikopter se nije pojavio. S blagim osjećajem panike u crijevima, Boz je odlučio hodati uz žičanu ogradu koja je opasavala naftno postrojenje, ali činilo se kao da se proteže u vječnost i s razočaranjem je shvatio da je snimanju možda došao kraj. Kao što je i njemu možda bio kraj ili barem kraj poglavlju o Velšaninu koji je ostavio ženu i pobjegao sa sobovima. Ako ga helikopter ne nađe, život kakav je poznavao također će biti gotov. 
Uskoro će zima i dani gotovo da neće postojati. Zaglavit će s ljudima koje nije mogao nazvati prijateljima jer nije čak ni znao kako se kaže prijatelj na njihovu jeziku, ali koje je iskreno zavolio zbog jednostavnosti njihova života, ustrajnosti njihova putovanja i zvonkog smijeha njihove djece. Ta djeca nisu imala nijednu igračku, no ipak su se stalno igrala. Jeo je svisca s njima i toliko sobovskog mesa da je gotovo stalno imao problema s probavom. Jednog dana uzdahnuo je od olakšanja na spomen kobasica dok nije otkrio da su napravljene od sobovske krvi, u crijevu od želučane kesice.

A onda je jednog dana spasio djevojčicu od utapanja. Nitko mu nije zahvalio, a njena majka bez suza je primila njeno promočeno tijelo, nije čak ni slegnula ramenima. Ali nešto se dogodilo. Dogodilo se prihvaćanje. Gledao je kako joj nanose medvjeđu mast na rane gdje je rebrima udarila o kamenje, a onda je izašao i gledao muškarce kako okupljaju životinje za kastraciju.

Za oko mu je zapeo srebrni bljesak i vidio je nešto nalik na mali buldožer kako se probija po snježnoj poljani prema ogradi. Sobogoniči su se ukipili. Bio je to još jedan od prizora za koji nije bilo mjesta u njihovom poimanju svijeta.

U kraju u kojem se renesansa nikada nije dogodila i gdje je znanost prvi puta stigla u obliku aviona koji je nisko prozujao iznad vrhova krošnji vozeći kartografe, geologe i jednog antropologa, već je i ograda bila nešto sasvim posebno. Nisu poznavali metal, sve svoje oruđe, sve što su imali načinili su od svojih životinja - noževi su bili napravljeni od rogova, mjehovi od utrobe, čak je i svojevrstan nakit bio izrađen od izrezbarenih papaka i malih rastegnutih trakica kože.

A sad je s njima bio Boz, čovjek koji je pisao pjesme kojima se prodaje donje rublje i belgijska čokolada. Čovjek koji se uzrujao kad mu je jedna kompanija rekla da ne može pustiti zvuk ukulela preko dvadeset sekundi gluposti. Boz i njegova kamera u pokušaju da shvati taj način života pun uzvišenog dostojanstva i nedokučivih izvora tuge.

Boz je gledao kako u daljini, s druge strane ograde, prema njima tetura i kotrlja se dvadeset i prvo stoljeće, s ogromnim čovjekom stisnutim u liliputanskoj kabini malog buldožera koji se činio kao da nikada neće moći izaći iz nje. Pušio je u kabini s potpuno zaleđenim vjetrobranom, kao da će ga sjaj točkice na kraju cigarete ugrijati unatoč strmoglavom padu temperature. Zbog oblaka dima i trzaja njegova ogromnog tijela dok je upravljao polugama djelovao je neljudski. Svi su gledali kako 
se mali buldožer zaustavlja i bili su opčinjeni prizorom muškarca koji se istiskuje iz kabine poput paste za zube koja izlazi iz tube.

Prišao je ogradi i uslijedila je duga tišina u kojoj su ga promatrali, a on je odmjeravao Bozov šutljivi klan. Nakon nekoliko minuta promuklim je glasom postavio nekoliko pitanja na ruskom, a mladi se Nenet približio da prevede.

"Tko je on?" upitao je Rus, odmahujući u smjeru Boza.

"On je čovjek koji radi film za nas. Došao je u zraku."

Ostali goniči potvrdno su kimali glavom iako nisu ni približno znali o čemu govore. Iza njih, jedan je mužjak soba važno dignuo njušku i uvrijeđeno frktao.

Rus je zamišljeno kimnuo.

"Treba li mu što?"

Mladić je pogledao Boza, pokazujući dlanove gotovo univerzalnom gestom.

Boz je vidio kako se put pred njim dijeli u dva pravca. Prvi, na kojemu igra karte i čeka prijevoz naftne kompanije, i drugi na kojemu će ostati s prijateljima i dovršiti putovanje, a tek onda razmišljati o tome kako će se, k vragu, vratiti kući. Može čekati klepetavi helikopter koji će ga odnijeti što dalje odande. Ili ostati ovdje, s ljudima koji su preživjeli atomske bombe, rudnike urana, medvjede, prisilni rad u gulagu na Boljšoj Nimniru i khitre vukove. lako će in možda na kraju dokrajčiti votka.

Znao je kojim putem krenuti, prema mjestu na kojem je zrak težak od mirisa amonijaka sobovske pišaline i gdje ga noću griju tijela njegovih susjeda, koji svi hrču kao pile, a slabašno jutarnje svjetlo neopisivo je ljepše od krajolika bilo kojeg slikara. Baš kao što sob predvodnik krda, hunyuk, određuje ritam kao šaman bubnjem, i on je znao kojim će putem krenuti. Amdip, duy, erimken. Putem koji vodi u nepoznato, što mu se sada činilo neobično poznatim, poput lica njegove stare majke koja mu se smiješi kroz breze, još uvijek ponosna na svog sina lutalicu.

\section{c) (i) (9)}

Creative Commons Attribution-NonCommercial-NoDerivatives 4.0 International License 